\title{
JUURNAL.RU
}

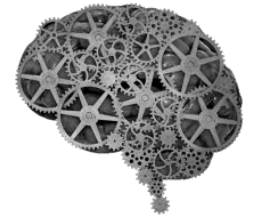

COMPANY GROUP "INTELLEKT"

\author{
Воробьева О.Н. \\ Кубанский государственный университет \\ Краснодар, Россия
}

doi: 10.18411/lj2016-9-1-04

idsp 000001: lj2016-18-1-04

\section{Субъективные переживания юности современной молодежью: результаты эмпирического исследования}

В настоящей статье внимание сфокусировано на рассмотрении субъективных переживаний юности современным поколением. Каждый человек за свою жизнь проходит несколько стадий развития, миновать которые он не в силах. Несмотря на то, что каждый этап открывает перед индивидом новые возможности и позволяет приобрести новые качества и знания, наиболее ярким периодом все же является юность как переход от детства к молодости. Безусловно, С. Холл был прав, называя подростковый период «периодом бури и натиска»[1. с. 278], поскольку это самое тяжелое испытание для молодого человека, когда ему необходимо выстоять перед внешними факторами и найти самого себя, свой жизненный идеал. Особое значение в этот момент приобретают переживания молодого человека, его желания и стремления, идеалы, страхи и увлечения.

Исследование базируетсяна модифицированной методикеавтобиографических записей, примененной М.М. Рубинштейном в 1920е гг.Результаты исследования опубликованы в работе «Юность по дневникам и автобиографическим записям»[2]. Вопросникбыл несколько скорректирован нами, в том числеприведен в соответствие с современными лексическими оборотами. В ходе проведенногоисследования нами было собрано42 автобиографические записи, пригодные для анализа. Следует оговорить, что количество девушек, готовых принять участие в исследовании,значительно превысило количество юношей. Анализ полученных жизненных историй включал в себя ряд категорий, позволяющих получить наиболее полные и системные знания о проблеме 
исследования. Остановимся на них подробнее.

Физический переход. Большинство юношей не заметило физических изменений в этот период: «Свой переход от детства к отрочеству я не помню». Примерно половина девушек не заметила данный период: «Переход от детства к отрочеству как физически, так и психически прошел довольно незаметно». С физиологической точки зрения подростковый период характеризуется рядом изменений, которые не могли не заметить респонденты: «Определенно точно помню, что начала болеть грудь, немного изменился голос, высыпало все лицо прыщиками. Еще стала замечать за собой прибавление килограммов к весу». Проблемы с кожей, которые присутствовали далеко не у всех авторов наших историй, становились действительно тяжелым испытанием для многих подростков: «Это перевоплощение из мальчика в парня было ужасно. Это как «гадкий утенок» только в обратной перемотке. < .. > Были у меня прыщики на лице, благодаря которым я все больше и больше погружался в себя». Помимо проблем с кожей, для подростков, в большей степени для девушек, болезненным является вопрос конституции тела: «Мне не нравилась моя фигура - слишком большой живот, большие бедра и при этом небольшая грудь, в подростковом периоде это переживалось особенно остро». С периодом взросления девушки также отмечают половое влечение, чего ни один из юношей не указал: «Я поняла, что у меня начинается подростковый период лет в 12 , когда отчетливо почувствовала физическое влечение и интерес к сексу».

Психические изменения. Более существенные и тяжелее переживаемые изменения происходили с подростками в психическом плане: «Из-за комплексов я начала закрываться, отдаляться от людей. < ..>. Я стала более раздражительной, что<...> еще больше меня раздражало». В подростковом периоде ясно проявляются изменения взаимоотношений с родителями: «...я все больше и больше погружался в себя. А моя семья, состоящая из строгой матери, которая только полгода проводила со мной как в хаосе, а полгода была за границей по работе, только усиливало мое погружение». Кроме ненужности родителям, друзьям, девушкам в этом возрасте также свойственнычувства жалости к самим себе, повышения требовательности, осуждения себя: «Часты были приступы самобичевания: слезы, всхлипывания о своей ненужности и некрасивости». Для многих отсутствие взаимопонимания с мамой превращается в травму и остается в 
памяти навсегда: «Родился второй братик, и внимания мамы мне не хватало вовсе. Без того отношения с ней были не простые, так в тот период стали просто невыносимыми».Проблемы с лишним весом также становились причиной конфликтов с родителями: «Родители тоже применяли немного жестокие методы намекания на излишний вес. $<\ldots>$ Родители на Новый год сделали мне необычный подарок - напольные весы». Еще одной чертой, свойственной подросткам, является стремление к познанию нового, к саморазвитию и самоанализу, а также восприятие жизни под другим углом:«Начался безудержный анализ всего и вся, безостановочный. Сначала хотелось понять природу изменений «религиозного опыта», потом самой боли, потом боль стали вызывать и другие «неприятные открытия». Анализ межличностных отношений, анализ явлений общественных, психологических. Анализ, анализ, и еще раз анализ».

Рост умственных интересов. Многие респонденты отметили, что в подростковом периодеу них стал активно проявляться когнитивныйинтерес, стремление к различным областям знаний, всему новому и неизведанному: «Я был очень любопытным, меня интересовало все, где я мог уединиться. Чужое присутствие меня только напрягало».Для многих подростков мир литературы и гуманитарных наук открывается иначе в этот период: «Читала я очень много. < .. > Читала все: романы для девочек, детские детективы, постепенно переходя на книги посерьезней. Приключения, детективы, романы - готова была сутками сидеть за чтением». Порой авторы историй были очень самокритичны, характеризуя свое развитие следующим образом: «Сейчас я могу сказать, что умственное развитие в тот период было «недалекое», слушала какую-то странную музыку, совсем не хотела учиться».

Любовь и дружба. Часто молодые люди, находясь в состоянии поиска самих себя, выбора своего жизненного пути, не могут для себя решить, что же им важнее: «К чему я стремилась, сложно сказать. С того времени и до сих пор мне всегда комфортно наедине с собой, я ценю и иногда нуждаюсь в одиночестве. Но то же самое можно сказать и об общении с друзьями. В целом, к дружбе я стремилась...».Стремление к обществу сверстников порождали разные чувства у подростков: «С друзьями я вела себя как командир. Я дружила всегда с более слабыми людьми, которым могла говорить, что и как делать, чему-то научить, а когда мне не удавалось сделать все по своему, то я шантажировала и 
манипулировала ради того, чтобы сделали так, как я хочу». «Я боялась что-либо пропустить... Меня пугало то, что, если меня лишний раз не увидят, то меня забудут». «Противоположного пола я боялась. Папа всегда внушал в меня страх. Грубая сила. Холодность. Равнодушие. <.. > Все это вылилось в панический страх перед мужским полом. Доходило до того, что идя по улице, я сворачивала с дороги, если впереди видела мужчину или парня».

Сексуальные проявления юности. Физиологические изменения, половое созревание, общение с противоположным полом - естественные проявления подросткового периода: «Половое влечение я начала испытывать лет в 16, проявлялось оно самым обычным образом, мне нравилось когда меня целуют, обнимают, было какое то неизведанное чувство, хотелось чего-то большего, чем просто поцелуи». Автор другой истории так описывает этот период: «Ну, половое созревание играло по максимуму: сверхвозбудимость, фантазии всякого рода, мастурбация, отношения с противоположным полом (преодолевая робость), поцелуи... Проявился интерес к обучающей «литературе» сексуального характера». Интересно, что истории юношей содержали указания на стремление к семье, среди девушек же этого не было, там преобладали романтические проявления: «В 16, как я уже писал, у меня сформировалась цель - завести семью, - и я сделал для себя вывод, что хочу всю жизнь прожить с одной девушкой». «Конечно же, мне нравились мальчики, но это скорее было для того, чтобы мечтать. Я не хотела встречаться и дружить, я хотела мечтать. Приписывала понравившемуся мальчику суперкачества и мечтала».Половое влечение, физиологические изменения вызывают у подростка множество вопросов, порой страх, преодолеть который помогает кто-то из близких людей: «Делилась секретами и спрашивала совета я обычно со своей подругой. Хотелось когда-то спросить у мамы или что-то рассказать, но мне было очень стыдно, а подругу-то что стыдиться, она же ничего не скажет и не поругает».Конечно же, были и сестры в качестве «старших товарищей», помогающие найти ответы на интересующие вопросы: «Делилась этим с сестрой, которая во многом помогла мне тогда в вопросах отношений с парнями и первой близости». В отличие от юношей, девушки получали необходимую информацию еще и из соответствующей литературы, которую зачастую покупали им мамы.

Нравственные воззрения и стремление к самостоятельности. Поиск 
себя, выбор своей жизненной стратегии формируют у подростков определенное восприятие окружающей действительности: «В тот период я был очень требователен к себе, жесток, строг и никаких самооправданий не принимал».Подростковый период не только «требует», но и воспитывает в молодом человеке различные качества: «Но есть такие правила, ценности, установки, которые у меня сложились еще в том возрасте, остаются у меня по сей день, укрепляются, которые с годами крепнут и оправдываются на практике. Справедливость, честность, доброта, умение слушать и выслушать, любовь к чистоте, минимализм в одежде, любовь раз и навсегда». Наряду с формированием нравственных воззрений, в подростковый период для человека важным становится еще одна черта - самостоятельность: «Считала себя самостоятельным ребенком. В главном тогда амплуа ученика была независима от помощи родителей, поэтому их попытки вмешаться без моего желания принимала в штыки».

Эстетические проявления юности. Подростковый период полон различных переживаний, эмоций.Найти вдохновение и выплеснуть его помогает мир искусства: «Я начала смотреть на искусство, как на отображение личности и ее переживаний». «Писала стихи, в городе стала лауреатом конкурса». Высокое искусство, а именно театр, больше свойственно девушкам: «Я обожаю театр за то, что после его посещения ты выходишь абсолютно обновленным и чистым». Особое значение играет и музыка, многие с удовольствием занимались танцами: «Но даже в самые тяжелые периоды моей жизни, даже тогда я не смогла оставить свои танцы. Это то, с чем я никогда, наверное, не смогу расстаться. Когда я начинала злиться на всех, я просто уходила в зал и танцевала до синяков на ногах, выражая все свои эмоции через танец».Некоторые подростки занимались самовоспитанием эстетического вкуса: «Развитие эстетического вкуса было основным моим проявлением, обожала и уже тогда разбиралась в литературе, поэзии, музыке, архитектуре; рисовать не умела, но могла оценить по достоинству. Стихи писала лет с 14 и принимала участие во всех литературных конкурсах».

Роль кружков в юности. Пожалуй, еще одним проявлением стремления найти себя, развить в себе какие-либо способности, является занятие в различных секциях, кружках и школах: «И в 14 лет я открыла для себя волейбол. До конца школы страстно занималась волейболом, несмотря на запрет из-за болезни шеи».Юноши и девушки занимались спортом, ходили в художественную и 
музыкальную школу, некоторые увлекались танцами: «Я танцевала. Считаю это творческим развитием. Любила очень танцы и с удовольствием танцевала».

Типы юности. Юность - пора мечтаний, надежд, переживаний о будущем, поэтому юноши и девушкивспоминают себя мечтателями: «Я мечтал обо всем. И желательно сразу. Часто размышлял, кем стану в будущем, думал о следователе, преподавателе, ученом, военном и т.д. и т.п. по списку».Для девушек это чаще мечты о любви, семье: «Мечтала я о большой и неземной любви, как в фильмах», были и мечты о будущей успешной жизни: «Я мечтала всю жизнь стать богатой, и известной. Я себе четко представляла, как я руковожу фирмой, хожу в классической дорогой одежде, у меня личный водитель черного автомобиля».Наряду с мечтателями, конечно же, есть те, для кого не существует «облаков», а есть только реально происходящие события и трезвый взгляд на них: «Я был реалистом, хотя и сейчас им являюсь. Во всем вижу плюсы и минусы,и взвешиваю».

Романтика юности.Поскольку многие подростки - мечтатели, им свойственно стремиться к чему-то уникальному, интересному, например, путешествиям: «В 14 лет летом с папой мы поехали через всю Россию на машине искать дом. Это лето было одно из лучших моих воспоминаний, т.к. у меня всегда была тяга к путешествиям, а тут еще такое яркое». Тяга к приключениям была практически у всех ребят: «Были друзья, с которыми мы искали приключения...». Более серьезные стремления, свойственные людям постарше, тоже присутствовали у авторов автобиографических историй: «Я думала в то время о героизме. Мне была очень близка тема патриотизма... Я думала, что если бы я жила в то время, то из меня получился бы не плохой боец за Родину».

Зависть в подростковой среде. Пожалуй, зависть была свойственна человеку во все времена, но, как оказалось, многие авторы историй не имели (либо скрыли) поводов для зависти: «Я никогда не завидовал своим сверстникам. Это было ниже моего достоинства». Хотя были и те, кому все же присуще это чувство: «Завидовал сверстникам в двух случаях - когда степень их свободы от взрослых была выше моей, и когда у кого-то отношения с противоположным полом складывались счастливее».Девушек же больше волновали физическое превосходство, а именно: чистая кожа, стройная фигура, что показывает их желание и стремление всегда быть красивыми, в центре внимания. Однако больше 
всего девочки завидовали материальному благосостоянию других: «Да, зависть была и проявлялась она в основном по отношению к вещам, компьютерам, велосипедам и прочей материальной ерунде, так как семья была небогатая, и очень многое нельзя было себе позволить».

Итак, результаты нашего исследования, представленные здесь в самом кратком виде, показали, что период юности очень важен в становлении личности, так как именно в этот момент человек чаще всего выбирает свой жизненный путь, происходит его взросление, выработка собственных взглядов на жизнь. Характеристики юношеского периода безграничны, а восприятие молодыми людьми самих себя уникально. Автобиографические записи показали, что подросткам свойственны общие черты и проявления субъективных переживаний, однако, помимо общих черт есть и уникальные, особенные черты, которые раскрывают безграничность мира юности. 


\section{Литература:}

1. Обухова Л.Ф. Детская психология: теории, факты, проблемы. 3-еизд. - М.: Тривола, 1998.- 352 с.

2. Рубинштейн М.М. Юностьпо дневникам и автобиографическим записям. М.: Изд. Высш. пед. курсов при Моск. высш. техн. уч-ще, 1928. - 276 с. 